\title{
Elongation Factor 1-Gamma
}

National Cancer Institute

\section{Source}

National Cancer Institute. Elongation Factor 1-Gamma. NCI Thesaurus. Code C38966.

Elong ation factor 1-gamma (437 aa, $\sim 50 \mathrm{kDa}$ ) is encoded by the human EEF1G gene.

This protein may play a role in the formation of the elong ation factor 1 complex. 